\title{
15. From racial hoaxes to media hypes
}

Fake news' real consequences.

Andrea Cerase and Claudia Santoro

Vasterman, Peter (ed.), From Media Hype to Twitter Storm. News Explosions and Their Impact on Issues, Crises, and Public Opinion. Amsterdam University Press, 2018

DOI: $10.5117 / 9789462982178 / \mathrm{CH} 15$

\begin{abstract}
Racial hoaxes are becoming a popular discursive strategy to disguise racism, as well as a powerful means for triggering waves of fake news and outraged comments both on mainstream and social media. Built on grounds of plausibility and consistency with existing narratives, racial hoaxes may remain latent for a long time, and periodically emerge when negative stereotypes can be framed as actual news stories. Racial hoaxes have relevant political and social implications: spread across multiple channels, they can foster exclusionary discourse on immigration, migrants, refugees, and other minorities, with concrete consequences on people and policies. In particular, far-right movements embrace hoaxes as a great opportunity to advocate their claims and legitimate their calls for violent action.
\end{abstract}

Keywords: media hype, racial hoaxes, exclusionary discourse, fake news, refugees, far-right movements

\section{Theoretical background}

Racial hoaxes are becoming a popular discursive strategy to disguise racism. This concept has mainly been used in US legal and criminological fields, aimed at exploring the connection between racial stereotypes and related practices in policing, and shifting criminal responsibility from a white offender to a fictional black predator (Russell, 1998). Nonetheless, this concept could be scrutinized from wider social and communicational perspectives, looking at how racial hoaxes are created and circulated, and how they affect ethnic relations. The concept also provides powerful 
insights into study how prejudices and stereotypes are objectivized, and how hostility tales turn into social action. Moreover, racial hoaxes should be a relevant matter for communication studies, since they involve both mainstream and digital media, and have relevant consequences on public.

In the age of populism, since one of the worst concerns of common people is regarding security, immigrants and minorities tend to be held responsible for crimes, poor levels of safety, and any deterioration of urban and social environment. Moreover, research has shown that media coverage can negatively affect attitudes towards immigration and immigrants (Boomgaarden \& Vliegenthart, 2009). Given a general negative orientation towards minority members, the rise of crime-related news can easily turn into a discourse of threat, fear, and danger, until 'the original facts quickly became obscured in a tide of outrage and condemnation' (Moore, Mason \& Lewis, 2008: 20).

Both in Europe and Italy, any single news concerning immigrants, refugees and minorities is likely to trigger a chain of reactions and interactions, building up huge news waves in the media or rapidly spreading social epidemics on social media. ${ }^{1}$ As traditional media grab people's attention on certain events, social media are the field to express outrage, public discontent, and even open manifestations of blatant racism.

In addition, the virality of social media like Facebook and Twitter sometimes may be intentionally amplified by click-baiting strategies used by newsmedia, aiming at catching users' attention through a misleading presentation of headlines and leads (Chen et al., 2015).

\section{Racial hoaxes and media hypes}

In order to provide a definition of 'racial hoaxes' for the purposes of this chapter, one may begin from Katheryn Russell's criminological perspective (1998: 70). Enlarging her reflection, authors propose a definition of racial hoaxes as:

An intentional attempt to produce, circulate or boost: an allegation of a crime; a threat posed against someone's health, security or safety; a violation of social norms; a challenge to social hierarchies or any other supposed deviant behaviour. Such attempt aims to spread outrage, blame and social exclusion. It targets an individual or a group because of race, ethnicity or religion, while fostering hate and discontent. 
Although racial hoaxes are not founded, both politicians and mainstream media are likely to include them in their political or debating agenda, building a new kind of media hype, based on plausible - yet fake - news, rather than on real events. A strong characterization of refugees as economic opportunists occurs both in Italy and in other European countries, along with strong hostility in media discourses about immigrants and refugees (Cerase, 2013; Holmes \& Castaneda, 2016). Such hostility themes are likely to be applied to other 'disturbing' minorities, such as the Roma, from time immemorial subjected to social exclusion and racial control (see Sigona \& Trehan, 2009).

Maneri (2013, infra) found outrage to be a key characteristic of both media hypes and moral panic theories. Media play the role of guardians of public interests, articulate public discontent, attract audiences, and establish publicly their agenda-setting power (Greer \& McLaughlin, 2012). This helps media sell scandals and outrage to their audience as well-packed stories, in an 'easy-to-open' package, with a clear characterization of the characters and a spectacular plot (Ruigrok, Scholten \& Vasterman 2007:4). Since the early attempts to build a media hype theory, the role of outrage in boosting news waves is sharply recognized (Vasterman, 2005). Afterwards, further researches found a somehow circular relation between media hype and the social outrage, which is triggered and re-inflated by media hypes (Vasterman, Scholten \& Ruigrok, 2008; Elmelund-Præstekær \& Wien, 2008; Wien \& Elmelund-Præstekær, 2009; Cerase, 2011a).

Both racial hoaxes and media hypes are clearly propelled by outrage, used as combustive agents to trigger the self-inflating dynamic of both phenomena. An outraged public urges news desks to a wider coverage of certain issues, while outraged users express frustration and anger sharing contents on social media. ${ }^{2}$

\section{Towards a qualitative approach}

The first aim of this chapter is exploring how racial hoaxes develop within media hypes, while comparing their dynamics. Since its first steps, theory has been developed within quantitative approaches, by using methodologies such as content analysis. Most empirical studies begin with or contain a 'snapshot' of media waves, drawn as time-series to measure the variations in amplitude of media coverage (news stories) over the time (Vasterman, Yzermans \& Dirkzwager, 2005; Elmelund-Præstekær \& Wien, 2008; Wien \& Elmelund-Præstekær, 2009; Giasson, Brin \& Sauvageau, 2010; Cerase, 2011a; Vasterman \& Ruigrok, 2013). 
Other researchers combined quantitative (content analysis) and qualitative (discourse analysis) methods, to explore how news wave can trigger change in general discourse on a specific issue (Paimre \& Harro-Loit, 2011; Maneri, 2013). Others investigated internet environment, introducing a mixed method to support an in-depth analysis. The need to improve awareness about a certain phenomenon led authors to put under scrutiny narratives, contexts and key activities to recognize main features of social media hype: online statistics have been combined with qualitative approach to better understand reasons beyond dynamics of such waves (Pang, 2013).

Maneri (2013) suggested extending the analysis to qualitative dimensions of the hype, as internal discursive dynamics, also highlighting difficulty in measuring abstract concepts such as disproportionality, concern, and consensus, which play a central role in media hypes production. He also urged considering power and consensus as key dimensions to investigate both media hypes and moral panic. Investigating racial hoaxes, and their related media hypes, should also draw on critical discourse analysis (Van Dijk, 1992, 2000; Reisigl \& Wodak, 2005).

Racial hoaxes are part of a wider discourse on power distribution in a racialized society, grounding on different strategies to maintain a racialized status quo, which may become evident as hostility themes (Leudar et al., 2008) and news frames (Bruno, 2014). Racial hoaxes work when felt plausible, and when they appear consistent with pre-existing discourses, narratives, and news frames. Therefore, such exploratory research aims at investigating qualitative conditions under which fake news concerning racial issue can turn in a (social) media hype.

With the aim to assess impact of racial hoaxes in public debate and political agendas, authors collected eighty-five cases, which took place in Italy between March 2014 and October 2016. Cases were retrieved them from Facebook and Twitter queries, search engines (Yahoo and Google news), printed media, news aggregators and anti-hoaxes specialized blogs. Each case collected news, graphics (memes), social media content and reactions, related trigger events, news follow-ups, data about sharing and queries, both in mainstream and social media.

Each racial hoax case was verified and analysed, in order to 1) identify trigger event and original source; 2) collect data about reach and sharing (when available); 3) retrieve any relevant detail about the incident; 4) collect data about media coverage and consonance; 5) retrieve Google Trends data (if available); 6) describe and explain any interactions between media and social media; as well as 7) relevant social and political reactions resulting from the hoax. 
Hoaxes were categorized according to their topic: (1) 'health threat'; (2) 'economic threat'; (3) 'criminal threat'; (4) 'other/not classified'. In sixty-six out eighty-five cases, it was possible to include the hoaxes in in one of the first three above-listed categories. The dominating topics were, respectively, economic, criminal, and then health threats, providing a reasonable base to ground some generalization and explicative hypothesis. ${ }^{4}$

In this chapter, authors present three case studies. Each of them belongs to one of the topics used to classify the case set: diseases spreading (health threat), parasitism and welfare exploitation (economic threat), and inclination to commit crimes (criminal threat). The case studies resumed and synthesized common features and dynamics emerging from a wider sample of incidents. The selected cases where chosen for their suitability with the above-mentioned definition of racial hoax, therefore real news, stories that were impossible to verify, and comments were excluded.

The recognition was mainly oriented to achieving a better understanding of racial hoax dynamics, and shared characteristics of hoaxes and media hypes. Therefore, this exploratory research included a qualitative analysis on discourses, specific narratives, news frames, and particular racial hoaxes.

\section{Analysis}

The cases study presented distinctive features in terms of relevance (reach), longevity, match with pre-existent discourses, role of news media - which not only adopted hoaxes, but sometimes even generated them - and reactions of media, society, and politicians. The analysis found that racial hoaxes appeared to follow some features of media hype theory, of which they emphasized certain elements and characteristic. In particular, considering risk and security as dominant narratives in contemporary media (Altheide, 2002), they were often retrieved as trigger factors able to ignite a Media hype. In other cases, risk appeared as a grounded dimension, as a threat posed against natives' welfare. In addition, outrage was a distinctive pre-condition to propagate a media hype, creating premises to talk about racial hoaxes as a sub-category of media hypes, since fake news were used to trigger outrage by exploiting social media virality. When consistent with some particular pre-existing news frame (Entman, 1993; Scheufele \& Tewksbury, 2007; Van Gorp, 2007), a racial hoax can meet with the conditions to trigger and reinforce a massive content sharing on social platforms and a huge wave of outraged comments, following up previous information, news events, and situations. 


\section{The Ebola hoax}

A first topic regarded disguised racist attitudes following worries about alleged threats against public health. Cultural approaches to risk highlighted how fear about health risks may turn into a moral justification for exclusion of discriminated categories. According to Mary Douglas, prejudice and biases against 'others' are objectified as a risk (e.g. contracting an illness). As such, risks are de-politicized and presented as apparently neutral advice on the need to keep a community clean, safe and free from harm (Douglas, 1966, 1986, 1997). Furthermore, cleanliness is a recurring argument in ethnographic studies on stigmatization. Thus, immigrants, refugees, and Roma are frequently blamed for their alleged uncleanliness and poor hygiene (Rochira, 2014). Such well-established stereotyped representations tend to be turned into allegations of being infected or immune carriers of some weird and scary infectious disease (Resigl \& Wodak, 2005). ${ }^{5}$

The internet was the favourite channel for conveying false warnings about dangers of diseases transmitted by immigrants, including rumours about Ebola, which were retrieved in five out of eighty-five cases. ${ }^{6}$ From such a Foucauldian perspective, risk and disease might be also analysed as means to exert a disciplinary power on migrants and refugees. Hinting at alleged risks of disease allows for the legitimizing of control regimes and restriction in access policies.

One of the cases originated from 6 August 2014, when the Italian rightwing newspaper Il Giornale published news of an Ebola-infected Spanish missionary coming back home from Western Africa. The daily suggested that immigrants arriving in Lampedusa could spread Ebola too. Promptly, Matteo Salvini, leader of the Northern League party, commented on his Facebook fan page: 'Ebola disease arrives in Spain, first case in Europe, but Renzi ${ }^{7}$ and Alfano ${ }^{8}$ still continue with Mare Nostrum'. ${ }^{9}$ Both Il Giornale and Salvini posed the question as a possible risk, rather than a real event. Even so, their behaviour highlighted how traditional media and politicians can play a crucial role in triggering a racial hoax, subsequently amplified on social media. Next, a man posted a message on his Facebook profile, containing two images of people with Ebola. Graphics pictured a haemorrhagic crisis, warning about scientists' fear for three cases, which had supposedly occurred in Lampedusa. ${ }^{10}$ The Italian Postal Police rapidly shut down this man's Facebook profile, but they also had to remove such content from profiles of over 27,00o Facebook users, who, in the meantime, had shared it. A few hours later, Health Minister Beatrice Lorenzin had to release an official statement in Parliament, clarifying and reassuring 
about the health conditions of immigrants staying in Lampedusa's shelters. Three days later, local associations of hoteliers in Lampedusa and Linosa announced civil and criminal legal action against those who had spread this false and alarmist news, which caused disappointment and outrage among Lampedusa's inhabitants. The associations also announced a ten million euro claim for damages, given a sudden wave of cancellations of bookings after the hoax spread.

This case presented a number of relevant insights for the future development of media hype theory. Furthermore, the involvement of politicians and a minister appeared to be consistent with Elmelund-Præstekær and Wien's additional reflections about the role of political actors in media hype debate. This case also underlined a relevant connection with the 'social amplification of risk' theory, whose theoretical relevance has been recognized by Vasterman and other media hype scholars (Vasterman, 2005; Vasterman, Yzermans \& Dirkzwager, 2005; Vasterman, Scholten \& Ruigrok, 2008; Vasterman \& Ruigrok, 2013). The case suggested how social media may have a prominent role as a 'social amplification station' (Kasperson et al., 1988, Kasperson \& Kasperson, 1996), able to magnify a real or alleged risk. ${ }^{11}$ Furthermore, it also showed how risk arguments can be manipulated for a hidden political agenda, exploiting public concerns and fears to disguise racism and support far-right and populist issues. A recall to various forms of risk (e.g. health, environment, food, crime) may be also retrieved in apocalyptic narrative and imagery of populism (see Heller, 2002; Edwards \& Gill, 2002; Power, 2007).

\section{The thirty-five euros hype and hoax}

Economic threats (and risks) represent another argument used to justify speeches and policies against migrants and asylum seekers. Systemic factors, such as the financial crisis, increased social conflicts and the rise of right-wing populist issues in politics are 'exploited' to ride discontent and turn outrage into social discrimination towards immigrants, refugees, and minorities at large, depicted as 'undeserving beneficiaries of the welfare state' (Kriesi \& Pappas, 2015). Unsurprisingly, thirty-one out of eighty-five corpus cases concerned alleged abuse of welfare by target groups.

Commencing from March 2014, news about migrants being paid thirtyfive euros per day by the Italian government spread quickly. The news storm (over 10,000 news articles retrieved from Google News) built on a long-existing hostility tale of immigrants exploiting national welfare, but was fuelled by data regarding sustenance costs of asylum seekers. As 
media hypes, hoaxes are more likely to occur when they fit with the overall discourse on a particular topic, and confirm pre-existing beliefs.

Traditional media published articles about the real costs of immigration, specifying that the figure of thirty-five euros originated from estimations formulated by immigration centres on the average costs of asylum seekers' stay. ${ }^{12}$ The press also reported that these resources came from European and national funds allocated to asylum, and that assisting asylum seekers and refugees is compulsory under international treaties and guaranteed by the Italian constitution. ${ }^{13}$ However, even debunking contributed to keeping the hoax alive, as data retrieved from Google Trend showed.

The media hype about costs of immigration inflated because of historical, social, and discourse-related features. It conveyed well fears regarding lack of resources connected to the financial crisis, but it also built on the typical dichotomy 'us' vs 'them'. In fact, based on these arguments we ('us') are not the problem: 'they' are stealing public money and are taking advantage of our welfare system. Moreover, the use of numbers is a common persuasive strategy in news discourse. Such racial hoaxes strive to displace focus from racial inclinations towards (unfounded) claims for economic rationality and

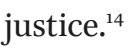

Building on the pre-existing news frame of migrants as a threat for national economy, this case study presents peculiar characteristics. Certain media (including traditional ones) started building on the (untrue) fact that the government gave migrants (including undocumented, economic, and European migrants, not only asylum seekers and refugees) thirty-five euros per day. ${ }^{15}$ Within the media hype of immigration costs, this fake news triggered a media hoax, aimed to polarize immigration debate and reinforce public racist or intolerant attitudes. Outrage motivated individuals circulating the hoax. Reasons motivating the success of the related media hype resulted amplified and reinforced. Numbers were used as a discourse strategy to present reliable sources and impressive figures, thus creating a sense of danger.

Whereas media coverage has shown attenuation, this media hoax was reinforced by hundreds of social media memes and articles, also national media. The hoax generated social reactions, which were covered as news and kept reinforcing the hype, along with other hoaxes founded on economic threats. The pretended revolt of refugees demanding to have plasma TV displays in their rooms, and refusal of food provided by immigration centres are news stories repeatedly covered by online portals and printed media in the monitored period. Any time there is the chance to reinforce this argument, the (fake) issue is recalled by certain media outlets, as if its hype would never decrease. The hoax is often used to compare immigration 




Figure 15.1. Search queries for immigrants + 35 euro (March 2014-October 2016)

resources and money assigned to other categories (as poor people, elderly, or those affected by earthquakes), which belong to the 'us' category, widely represented as unprivileged, threaten group.

Consequently, the belief that migrants receive thirty-five euros per day to stay in Italy influenced a broad audience, and - for many people - it converted in common-sense knowledge. Following diverse degree of truthfulness and credibility, (user-generated) social media posts, and news stories contributed transforming fake (yet credible) news in what is considered a fact by many people. Figure 15.1 illustrates such Karstic tendency, also highlighting a peak in correspondence with the immediate aftermath of Amatrice's earthquake, ${ }^{16}$ when a further version of such racial hoaxes hyped on social media.

\section{Racial hoax and purported crimes}

Summarizing a broader debate, Palidda (2011) observed that migrants and minorities criminalization appears as a common feature both in European and non-European countries (North America, Australia, Japan ${ }^{17}$ ). Mainstream media seem to play a specific role in such a process of social construction of migrant and minority members as a criminal threat, and Italy is no exception. Researches on moral panics and news waves concerning immigrants' crimes highlighted impressive points of contact with the results of Stuart Hall's studies, dating back over forty years (Hall et al., 1978). Other researchers observed how, since the 1980s, the Italian media's portrayal of migrant and minority members has crystallized in a freeze frame where they still appear as criminals, suspected or victims of crimes (Binotto, Bruno \& Lai, 2016). Racial hoaxes take advantage of such representation to convey any kind of fake news, even if only vaguely consistent with this news frame.

The cases corpus includes news of Romanian gangs giving people 'spy key holders' in order to follow their movements, of sexually harassing young 
children, of a Japanese tourist reacting to an attempted robbery by bashing three Roma boys, of migrants arrested for throwing stones at a school, and countless similar cases. Such incidents recurred in twenty-six of the eighty-five hoaxes, following the relevance of blaming and scapegoating in such a discriminating strategy.

At the end of August 2015, G.L., a twenty-year-old student from Caltanissetta (Sicily) was charged with inciting racial hate. Italian Police authorities closed his website, senzacensura.eu (nocensorship.eu), for publishing fake news about immigrants, refugees, and Muslims. The content concerned gruesome and defaming situations: the perfect clickbait for both racists and scared citizens. Typical headlines of fake news were 'Nigerian man rapes mother and daughter. The husband throws acid on his penis'; 'Catania, 15 y.o. burnt alive by immigrants: massacred for being Christian'; or 'Immigrant rapes a 7 y.o. little girl. Her father tears off his testicles and make her swallow them'. With this last article alone, the Sicilian boy 'received 500,000 hits, and earned 1,00o euros', as he declared in an interview to L'Espresso magazine. He added, "The purpose of my business was to draw attention to my site, aimed at gaining with banner ads and users' hits' (Di Fazio, 2015), confirming that 'social networking is not about affirming something as truth but more about making truth through endless clicking' (Lovink, 2011: 44).

In June 2016, regional newspaper Il Tirreno (from Tuscany) published an article attempting to calm the rising wave of hysteria following a hoax about Roma people being child kidnappers, which was spread on social media, but affected the whole community. Such urban legend, dating back centuries, is widely known across Europe, although it had no basis in recent Italian judicial history, with the sole exception of a single, disputed case in Ponticelli (Naples) in 2009 (see Clough Marinaro \& Sigona, 2011). Then, a Facebook post triggered the racial hoax and media hype. In a short text, a certain Federico wrote about an alleged attempt to kidnap two kids in a supermarket in Prato. The children were said to have been found in a bathroom, with their heads shaved, 'ready to be carried away by Gypsies'. 'Spread the word among as many people as you can to raise the alarm', he warned. The news story reported two other alleged cases in Montemurlo, another little village close to Prato, including denials from the police and storeowners. Nonetheless, this fake news kept circulating, and some websites re-published the false alarm several days after the police's press release. Once again, a racial hoax, leaning on a false, yet consolidated belief, spread from rumours, was revamped by Facebook, resulting in real-life events triggering a media hype. Social media were used to inflate mainstream media attention. Research highlights how in thirty-one out of eight-five 
cases, the mainstream media intervened to blame, debunk, or deny a racial hoax, in a bid to calm the rise of public worries about the consequences of fake news or rumours circulating on the internet.

Racial hoaxes may also spread with no direct involvement from mainstream and social media. They run by word of mouth, and may be reintroduced and inflated through social media. They may create worrying real consequences, such as the siege of and serious threats against a refugee shelter in Lamezia Terme (Calabria). In September 2015, a local elder claimed to be a victim of aggression, robbery, and torture by three young immigrants. While police investigated, rumours circulated in town, and some local politicians revamped them on Facebook. Despite the official notice released by police explaining that no evidence of crime was found, and that the elder was suspected of having simulated it, a shouting crowd surrounded the refugee shelter, hurling racial slurs and death threats towards immigrants and shelter personnel.

\section{Findings: Recurrent actors, forms, and structures}

In the entire case corpus, media played some role in the racial hoax cycle. In fifty-nine of eighty-five cases, the racial hoax provoked a media reaction: national and regional printed newspapers, online media, journalistic blogs, or other digital outlets joined the conversation. Among them, websites such as Voxnews.info, Imolaoggi and Tutticriminideglimmigrati (all immigrants' crimes) played a distinctive role in launching fake news on the internet, either entirely making it up or distorting features of an existing media hype. Although this matter has not been covered in this chapter, these kinds of web portals have explicit boundaries with far-right and racist movements (Ballone \& Sasso, 2015). National or regional printed newspapers also joined the fray: intervening in twenty-two out of sixty-one incidents, but mostly to blame manipulation, correct inaccuracies, and debunk racial hoaxes. In various cases, national news desks covered media hoaxes to the point of generating media hype. They attacked the Italian comedian and political activist Beppe Grillo who, on his blog, published a fake picture of a victim of terrorism in Zimbabwe, but presented the dead man as a victim of Ebola. At other times, the media covered fake news as if they were real: they reported on Roma looters arrested for stealing from ruined houses after Amatrice's earthquake, which turned out to be completely false. All the main newspapers propelled fake selfies of supposed Islamic State fighters shot in crowded public places in Italy. In three cases, coverage appeared to be tied to a massive 
and sudden wave of outrage and fear, which resulted in a significant social media hype. The analysis logged various attempts to monitor and counter racial hoaxes, and to belie and deconstruct them. However, anti-hoaxes web portals, articles from the web and printed media, stances by editorial boards, journalists, and intellectuals can be considered as 'articles on related topics' and 'opinions' that revamped the media hype's dynamics.

Twenty-five cases covered by national and regional newspapers involved political actors. Their role ranged from being authors of the racial hoax, facilitators of a climate in which the hoax originated (like Salvini in the Ebola hoax case study), attempting to ride the hype to influence political debate, ${ }^{18}$ feeding the hoax, or, being forced to intervene to debunk a hoax and stop its effects (like Minister Lorenzin in the Ebola case). Most of the time, politicians intervened to condemn a hoax, and usually do not comment on openly fake racial hoaxes. However, the analysis carried out showed that even with the kind of hoaxes that remain confined to blogs and social media, far-right groups interacted to exploit the generated outrage.

Social reactions have been observed in fifty-three out of eighty-five collected hoaxes. They ranged from random, disorganized, and outraged comments, mass content-sharing, the creation of social media protest pages and groups, online and offline petitions, request for damages deriving from the hoaxes (both from groups and individuals), and enquiries to press associations, anti-discrimination bodies, and police forces.

Racial hoaxes' most recurrent structure was the news story that copy journalistic language and formats. Sometimes they borrow (or imitate) the name of a famous newspaper or a press agency. They adopt conspiracy theories and present 'news they are attempting to hide (about immigrants [...])'. In doing so, they try to present themselves as an information source and as advocating natives' interests against threats posed by migrants, refugees, and minorities (or other targeted people). Such fake news encompassed newsworthiness criteria, journalistic rules, and tabloids' rhetoric forms. Exaggeration was aimed at worsening representations of the minority/target group. The exploratory research and analysis confirmed that racial hoaxes adopted the moral panic structure, by targeting 'folk devils'. As media hypes, hoaxes appeared to be sensation-seeking and fearmongering. They were more effective when leaning on pre-existing and shared discriminatory narratives, also consistent with strengthened hostility themes.

Themes such as risk and security generated or intervened in media hypes, confurming that diseases and threatening 'others' have become moral imperatives for both individuals and institutions (Garland, 2003; Lupton, 2006; Tulloch, 2008). Hence, analysing risk discourses also means 
considering the underpinning relations of power and domination, since risk relates to 'a problem of justice, faith, power, or money' (Zinn, 2008: 185).

Commodification of outrage ${ }^{19}$ clearly emerged as a strategy to (intentionally) propagate the hype. It was observed that fake news about immigrants, refugees, minorities is intended to be a kind of magic wand for objectivizing, justifying, and supporting discriminating or openly racist attitudes. Racial hoaxes provide a symbolic resource for expressing anger, disdain, and hostility towards minorities. ${ }^{20}$ In the last quarter of a century, outrage has become a sort of lingua franca in public discourse, able to permeate political debate, media outlets, and journalistic standards (Protess, 1992). Inciting racial hoaxes, political actors exploit outrage to grow audiences and manipulate them for political purposes.

A final consideration relates to the longevity of certain hoaxes. In some cases (as for the thirty-five euros hoax), the racial hoax's cycle never decreased and it assumed national interest. In other cases, even when a hoax was debunked (by specialized websites, media, and political actors), after three to five months, some 'online editors' used it as a source and re-launched it as actual news, pointing to a troubling development in the current information environment.

\section{Conclusions}

Considering media hype as a category for describing features and dynamics of a media-generated news wave, hoaxes have the distinctive feature of adding false information. In forty-two of the eighty-five analysed cases, (fake) news triggered dynamics of media hype, with different extents, lengths, and size. In others, hoaxes intervened at a later stage, to distort, manipulate, and exploit the media hype. Thirty-four social media hypes encompassed a classic media hype. Occasionally, (twelve out of eighty-five cases), racial hoaxes remained confined to social media and dedicated websites, failing to enter the media hype structure and dynamics.

The analysis suggests that the media hype theory can be used to explain the dynamics behind hoaxes, provided that 1) the majority of incidents triggered short social media hypes, even if they only last a few days, the process tends to replicate in a short time and scale the five stages described by Vasterman (2005); and 2) many racial hoaxes follow a Karstic trend, with sudden rises and falls of attention, and a long latency between two peaks: people's attention is likely to surface because of media attention for a particular issue or topic. Moreover, the same hoax recurred many times over months and years. 
Whereas the media hype theory (Vasterman, 2005) assigns the ability to develop a new storm to media (and their functioning), in racial hoaxes the attempt to spread false information is attributable to particular actors, i.e right-wing politicians, populist actors and - on social media - specific Facebook and Twitter profiles. In the case studies examined, the actors used outrage as a tool to maximize diffusion on social media environment, even using clickbaiting or explicit incitement to share content. Virality does the rest, amplifying racial hoaxes' circulation. Sometimes, authors managed to inflate hoaxes and overcome gatekeeper-journalistic barriers. Even when unmasked, digital and traditional media picked up and reported on hoaxes, intensifying an existing media hype.

In other cases, racial hoaxes did not trigger a media hype, but rather intervened at a later stage. Fake news may intervene when media coverage extends to other similar events and topics (Vasterman, 2005), adopting the hype theme and mocking journalistic formats in order to appear realistic. Surfing existing media hype, fake news created a racial hoax, with its own cycle. In the majority of cases examined, traditional media presented hoaxes as fake news and discussed them in a critical way. In some cases, right-wing and regional media, adopting the hoaxes' sensationalist and confirming nature, reported them as real news. In all cases, the racial hoax boosted and extended the hype, postponing its attenuation. Racial hoaxes even transformed fake news into tangible social reactions.

It is not easy to determine whether press campaigns aimed at tackling lies and restoring journalism reputation and credibility effectively counter racial hoaxes. Sometimes, they risk amplifying their diffusion and consolidation. They may reinforce the specific frame of reference, which unavoidably leads to feeding the news wave, also reinforcing the newsworthiness of the news theme and consolidating racial hoaxes as plausible truths (see Vasterman, 2005:515). ${ }^{21}$

Racial hoaxes have the potential to affect public opinion because people regard them as a source. Even when a racial hoax is obviously, comically, false, it circulates on blogs and social media, and, without the quality filters traditionally supplied by mainstream media outlets (Lee, 2016), in some cases it becomes public. As media hype theory suggests, being based on fake news does not impede hoaxes from triggering a storm of outraged reactions (such as content sharing and comments). These, in some cases, can flow on both digital and traditional media. The analysis originated a reflection on causes that may determine why some hoaxes remain confined to internet discussions, while others break through to the public domain. The variables observed in the case corpus suggested that the adoption of 
discourse strategies and journalistic formats assigned visibility to some hoaxes, which were covered by news media. Furthermore, the case-set hinted that hoaxes including political actors in the conversation had more durability.

Hoaxes erode media credibility when they are reported as 'real news'. Because of unchecked sources, such incidents may result in an additional deterioration of journalistic standards in southern Europe (see Hallin \& Mancini, 2004), already exhausted by organizational pressure, fast-paced newsrooms and the need to embrace infotainment news values. This means jeopardizing journalistic standards, privileging images instead of ideas, emotions rather than rational analysis, and avoiding the complexity of real life. It also dramatizes and exaggerates news presentation to attract new public (see, among others, Sparks \& Tulloch, 2000; Reinardy, 2010; for the Italian case see also Cerase, 2011b).

Racial hoaxes' most significant facet, however, regards their political and social implications: they have concrete consequences for target groups, people, and policies. In particular, far-right movements embrace hoaxes as a great opportunity to patronize their claims and legitimate their calls for violent action.

The current media hype on fake news seems focused on a theoretical debate, referring to the clash between governing elites. However, dealing with this topic as a philosophical dispute regarding the epistemology of the news, or concerning the ethics of propaganda, may be misleading. In fact, such an approach does not take into account fake news' real consequences, and the related effect of maintaining the racial status quo, as proved by the considered case catalogue.

Racial hoaxes are a relevant subject for further research, since they fully enter the process of construction of social problems, able to affect both politics and ethnic relations in communities and other social environments.

\section{Notes}

1. In Italy, UNAR (the national agency against racism and discrimination), confirmed the link between racism and the internet. Of 990 verified cases of racial discrimination filed by UNAR in 2014, 24.9 per cent concerned hate speech, which motived 12.4 per cent of 2009 incidents. The internet had a leading role in such processes: public instigation of racial hate on social media represented 89.2 per cent of complaints concerning media collected by the Agency (UNAR, 2014). Similar situations have been found in other European countries, as emerged during research carried out within the European project LIGHT ON (Boileau, Del Bianco \& Velea, 2014). 
2. According to Vasterman (2005), media hypes are characterized by: 1) presence of a key event (trigger event); 2) event originates a wave of news with a rapid growth and a significantly slower attenuation; 3) wave encompasses a strong consonance between different news outlets and media; 4) media coverage extends to other similar events and topics; 5 ) such coverage tends to generate social reactions, which are, in turn, covered as news (Vasterman, 2005). In addition, these media hypes are likely to cause significant interactions between political actors, who tend to strategically exploit opportunities to influence public debate and decisions making process (ElmelundPræstekær \& Wien, 2008).

3. Hoaxes themed on 'terrorism' have been considered a sub-category of 'criminal threat', while other topics such as 'identity', counting only a few cases, were assigned to other / non-classified.

4. For each hoax the analysis also considered (1) date; (2) title; (3) media on which was shared; (4) link; (5) whether national media diffused it; (6) whether local media diffused it; (7) reach (in terms of users); (8) trigger event; (9) longevity; (10) pre-existent discourses; (11) if media reacted; (12) how media reacted; (13) if there were social reactions; (14) which social reactions; (15) if politicians engaged in/reacted to the hoax; (16) topic; (17) if was part of /generated a media hype; (18) if it was originated from/generated a social media hype.

5. For a detailed account see, among others, Gallisot, 1985. As regards Italy, discourses and rumours about alleged and real cases of tuberculosis, scabies, AIDS and other diseases have been recorded by Italian academic sociologists since the end of 1980 (see Ferrarotti, 1998: 108) and regularly spread via media outlets.

6. Contagious diseases were cited in other eight out of eighty-five incidents.

7. Italian PM in charge at that time.

8. Italian Ministry of Interiors at that time.

9. Mare Nostrum was an Italian Government search and rescue naval and air mission to patrol sea and rescue immigrants in the Mediterranean. For further detail, see Massey \& Coluccello, 2015.

10. Lampedusa is the Southern Italian island, which is the first destination for migrants' boats arriving from Northern Africa and Middle East.

11. The Social Amplification of Risk Framework suggests looking at the communication process in wider sense, expanding analysis to any message conveyed from any source, by any channel, with no restrictions on direction flow, amplitude, and related audience, also taking into consideration messages conveyed unintentionally.

12. In Italy, local authorities that want to join the Sprar (the system of shelter for refugees and asylum seekers) have to present a proposal and financial plan. Operating expenses for the migrant, valued on average at around thirty-five euro per capita per day, therefore, may be subject to variations.

13. In the monitored period, some media outlets tried shedding a light on the benefits deriving from migrations, such as income deriving from 
the sector dedicated to immigration management, percentage of GDP deriving from foreigners-owned business, and contribution made to the national pension fund from migrants in Italy. However, these articles represented an exception and mainly appeared on traditional and specialised media.

14. Reflecting on denial of racism, Van Dijk noted that the latter 'is part of a strategy of personal, institutional or social impression management and ideological self-defence; it also is a form of socio-political management. It helps control resistance, and at the same time makes political problems of an ethnically or racially pluralist society more manageable. In sum, denial is a major management strategy' (Van Dijk, 1992: 97).

15. Under the aforementioned Sprar system, these funds are given to cooperatives, which support municipalities in the reception management. The estimated thirty-five euros covers expenses for food, housing, buildings cleaning and maintenance; only two and an half euros go to asylum seekers.

16. On 24 August 2016, a violent earthquake (M 5.9) struck Central Italy, causing 297 victims and razing to the ground Amatrice, Accumoli, Pescara del Tronto and other villages.

17. By the criminalization of migrants, we mean all the discourses, facts and practices made by the police, judicial authorities, but also local governments, media, and a part of the population that hold immigrants/aliens responsible for a large share of criminal offences'. (Palidda, 2011: 23).

18. Sometimes this resulted in paradoxical consequences. For example, in January 2016, internet trolls tweeted a famous photo of Jim Morrison, which caught the attention of the right-wing politician Maurizio Gasparri, who claimed that the picture was of Goran Hadzic, a criminal charged with over fifty robberies in Northeast Italy. Following the politician's 'what a shame' reaction, a huge wave of dismay and hilarious comments spread virally.

19. According to the definition proposed by Sobieraj \& Berry (2011: 20) the term outrage is 'a particular form of political discourse involving efforts to provoke visceral responses (e.g. anger, righteousness, fear, moral indignation) from the audience through the use of overgeneralizations, sensationalism, misleading or patently inaccurate information, ad hominem attacks, and partial truths about opponents, who may be individuals, organizations, or entire communities of interest (e.g. progressives or conservatives) or circumstance (e.g. immigrants)'.

20. As an example, similar patterns of justification (see Wodak, 2005) have been observed in protests in Tor Sapienza (Rome), Casale San Nicola (Urban area of Rome) and Gorino (a little village near Ferrara).

21. When authors wrote this chapter, between August and September 2016, they were unaware of the success that fake news and hoaxes would gain, starting from November 2016. Fake news became the topic of a new media hype, following and confirming Vasterman's media hype model adopted in this chapter. 


\section{References}

Altheide, David L. (2002). Creating fear: News and the construction of crisis. New York: Aldine De Gruyter.

Ballone, Andrea \& Michele Sasso (2015). 'La galassia della bufala sui social network. Il grande business di chi spaccia balle e odio'. L'Espresso. 31 March, Available at: http://espresso.repubblica.it/attualita/2015/03/31/news/la-bufala-e-l-odio -corre-viasocial-network-1.206543

Binotto, Marco, Bruno, Marco \& Valeria Lai (eds) (2016). Tracciare confini. L'immigrazione nei media italiani: L'immigrazione nei media italiani. Milano: FrancoAngeli.

Boileau, Anna, Del Bianco, Daniele \& Ramona Velea (eds) (2014). Understanding the perception of racism. Research as a tool against racism. Gorizia: Light On Project.

Boomgaarden, Hajo \& Rens Vliegenthart (2009). 'How news content influences anti-immigration attitudes: Germany, 1993-2005'. European Journal of Political Research, 48 (4): 516-542.

Bruno, Marco (2014). Cornici di realtà. Il framing e l'analisi dell'informazione. Milano: Guerini e Associati.

Cerase Andrea (2011b). 'Notizie prossime venture: tra informazione e intrattenimento'. In: Mario Morcellini (ed.), Neogiornalismo. Tra crisi e Rete: come cambia il sistema dell'informazione, 35-51. Milano: Mondadori.

Cerase, Andrea (2011a). 'Scandali sanitari, media hypes e capri espiatori'. In: Marco Binotto, Andrea Cerase, Antonio Di Stefano, Liuccio, Michaela, La malasanità in scena. Anatomia di un 'caso mediale', 27-78. Roma: Nuova Cultura.

Cerase, Andrea (2013). 'Colpevoli per elezione: gli immigrati nella lente della cronaca nera'. Comunicazionepuntodoc, 7, 69-88.

Chen, Yimin, Conroy, Niall J. \& Victoria L. Rubin (2015). 'Misleading online content: Recognizing clickbait as false news'. Proceedings of the 2015 ACM on Workshop on Multimodal Deception Detection. ACM, 15-19.

Clough Marinaro, Isabella \& Nando Sigona (2011). 'Introduction. Anti-gypsyism and the politics of exclusion: Roma and Sinti in contemporary Italy'. Journal of Modern Italian Studies, 16 (5): 583-589.

Di Fazio, Maurizio (2015). 'Vi racconto come ho fatto soldi a palate spacciando bufale razziste sul web'. L'Espresso, 16 October. Available at: http://espresso. repubblica.it/attualita/2015/10/15/news/vi-racconto-come-ho-fatto-soldiapalate-spacciando-bufale-razziste-sul-web-1.234576

Douglas, Mary (1986). Risk acceptability according to the social sciences. New York: Russell Sage Foundation.

Douglas, Mary (1996). Purity and danger. An analysis of concepts of pollution and taboo. London: Routledge. 
Douglas, Mary (1997). 'The depoliticization of risk'. In: Richard J. Ellis \& Michael Thompson (eds), Culture matters: Essays in honor of Aaron Wildavsky, 121-132. Boulder, CA: Westview Press.

Edwards, Adam \& Pete Gill (2002). 'The politics of 'transnational organized crime': discourse, reflexivity and the narration of 'threat". The British Journal of Politics and International Relations, 4 (2), 245-270.

Elmelund-Præstekær, Christian \& Charlotte Wien (2008). 'What's the fuss about? The interplay of media hypes and politics'. The International Journal of Press/ Politics, 13 (3): 247-266.

Entman, Robert M. (1993). 'Framing: Toward clarification of a fractured paradigm'. Journal of communication, 43 (4): 51-58.

Ferrarotti, Franco (1998). Oltre il razzismo: verso la società multirazziale e multiculturale. Roma: Armando Editore.

Gallissot, René (1985). Misère de l'antiracisme: racisme et identité nationale, le défi de l'immigration. Paris: Editions de l'Arcantère.

Garland, David (2003). 'The rise of risk'. In: Richard Victor Ericson \& Aaron Doyle (eds), Risk and morality, 48-83. Toronto: University of Toronto Press.

Giasson, Thierry, Brin, Colette \& Marie-Michèle Sauvageau (2010). 'Le Bon, la Brute et le Raciste. Analyse de la couverture médiatique de l'opinion publique pendant la 'crise' des accommodements raisonnables au Québec'. Canadian Journal of Political Science, (43) 2, 379-406.

Greer, Chris \& Eugene McLaughlin (2012), “This is not justice'. Ian Tomlinson, institutional failure and the press politics of outrage'. British Journal of Criminology, $5^{2}(2): 274-293$.

Hall Stuart, Roberts, Brian, Clarke, John, Jefferson, Tony \& Chas Critcher (1978). Policing the crisis. Mugging, the state, and law and order. London: Macmillan.

Hallin, Daniel \& Paolo Mancini (2004). Comparing media systems: Three models of media and politics. Cambridge: Cambridge University Press.

Heller, Chaia (2002). 'From scientific risk to paysan savoir-faire: peasant expertise in the French and global debate over GM crops'. Science as Culture, 11 (1): 5-37.

Holmes, Seth \& Heide Castaneda (2016). 'Representing the 'European refugee crisis' in Germany and beyond: Deservingness and difference, life and death'. American Ethnologist, 43 (1): 12-24.

Kasperson, Roger E., Renn, Ortwin, Slovic, Paul, Brown, Halina S., Emel, Jacque, Goble, Robert, Kasperson, Jeanne X. \& Samuel Ratick (1988). 'The social amplification of risk: A conceptual framework'. Risk Analysis, 8 (2): 177-187.

Kasperson, Roger \& Jeanne Kasperson (1996). 'The social amplification and attenuation of risk'. The Annals of the American Academy of Political and Social Science, 95-105. 
Kriesi, Hanspeter \& Takis Pappas (2015), 'Populism in Europe during crisis: An introduction'. In: Idem (eds), European populism in the shadow of the great recession, 1-19. Colchester: ECPR Press.

Lee, Timothy (2016). 'How social media creates angry, poorly informed partisans'. Vox, 26 October. Available at: http://www.vox.com/policy-and-politics/2016/10/26 /13413292/social-mediadisrupting-politics.

Leudar, Ivan, Hayes, Jacqueline, Nekvapil, Jiří \& Johanna Turner Baker (2008). 'Hostility themes in media, community and refugee narratives'. Discourse \& Society, 19 (2): 187-221.

Lovink, Geert (2011). Networks without a cause: A critique of socialmedia. Cambridge: Polity Press.

Lupton, Deborah (2009). 'Sociology and risk'. In: Gabe Mythen \& Sandra Walklate (eds), Beyond the risk society: Critical reflections on risk and human security, 11-24. Maidenhead: Open University Press.

Maneri, Marcello (2013). 'From media hypes to moral panics, theoretical and methodological tools'. In:Julian Petley, Chas Critcher, Jason Hughes (eds), Moral panics in the contemporary world, 171-193. London: Bloomsbury Academic.

Massey, Simon \& Rino Coluccello (2015). 'Introduction'. In: Idem (eds), Eurafrican migration: Legal, economic and social responses to irregular migration, 1-11. London: Palgrave Macmillan.

Moore, Kerry, Mason, Paul \& Justin Matthew Wren Lewis (2008). Images of Islam in the UK: The representation of British Muslims in the national print news media 2000-2008 Cardiff: School of Journalism, Media and Cultural Studies.

Paimre, Marianne \& Halliki Harro-Loit (2011). 'Media generated news wavescatalysts for discursive change: The case study on drug issues in Estonian print media'. Journalism, 12 (4): 433-448.

Palidda, Salvatore (2011). 'A review of the principal European countries'. In: Idem ( ed.), Racial criminalization of migrants in the 21st century, 23-30 Farnham: Ashgate.

Pang, Augustine (2013). 'Social media hype in times of crises: Nature, characteristics and impact on organizations'. Asia Pacific Media Educator, 23 (2): 309-336.

Power, Michael (2007). 'Corporate governance, reputation, and environmental risk', Environment and Planning C: Government and Policy, 25 (1): 90-97.

Protess, David (ed.) (1992). The journalism of outrage: Investigative reporting and agenda building in America. New York: Guilford Press.

Reinardy, Scott (2010). 'Need for speed onto internet clashes with journalistic values'. Newspaper Research Journal, 31 (1): 69-83.

Reisigl, Martin \& Ruth Wodak (2005). Discourse and discrimination: Rhetorics of racism and antisemitism. London: Routledge. 
Rochira, Alessia (2014). 'The dialogicality of cleanliness: 'Thematizing' the clean / dirty antinomy in the background of the theory of social representations'. Culture \& Psychology, 20 (2): 220-231.

Ruigrok, Nel, Scholten, Otto \& Peter Vasterman (2007). 'Media coverage of scandals: A modern version of Greek tragedy'. Conference paper, presented at ICA International Communication Association, TBA annual meeting, San Francisco, CA.

Russell, Katheryn (1998). The color of crime. New York: New York University Press.

Scheufele, Dietram \& David Tewksbury (2007). 'Framing, agenda setting, and priming: The evolution of three media effects models'.Journal of communication, 57 (1):9-20.

Sigona, Nando \& Nidhi Trehan (eds), (2009). Romani politics in contemporary Europe. Basingstoke: Palgrave Macmillan.

Sobieraj, Sarah \& Jeffrey M. Berry (2000). 'From incivility to outrage: Political discourse in blogs, talk radio, and cable news'. Political Communication, 28 (1):19-41.

Sparks, Colin \& John Tulloch (eds), (2000). Tabloid tales: Global debates over media standards. Oxford: Rowman and Littlefield.

UNAR, Relazione al Presidente del Consiglio dei Ministri sull'Attività svolta nel 2014. Rome: Unar.

Van Dijk, Teun A. (1992b). 'Discourse and the denial of racism'. Discourse \& Society, 3 (1): 87-118.

Van Dijk, Teun A. (2000). 'Denying racism: Elite discourse and racism'. In: Linda Wood \& Rolf Kroger (eds), Doing discourse analysis: Methods for studying action in talk and text, 179-193. Thousand Oaks, CA: Sage.

Van Gorp, Baldwin (2007). 'The constructionist approach to framing: Bringing culture back'. Journal of communication, 57 (1): 60-78.

Vasterman, Peter (2005). 'Media-hype. Self-reinforcing news waves, journalistic standards and the construction of social problems'. European Journal of Communication, 20 (4): 508-530.

Vasterman, Peter \& Nel Ruigrok (2013). 'Pandemic alarm in the Dutch media: Media coverage of the 2009 influenza A ( $\left.\mathrm{H}_{1} \mathrm{~N}_{1}\right)$ pandemic and the role of the expert sources'. European Journal of Communication, 28 (4): 436-453.

Vasterman, Peter, Yzermans, Joris C. \& Anja J.E. Dirkzwager (2005). 'The role of the media and media hypes in the aftermath of disasters'. Epidemiologic reviews, 27 (1): 107-114.

Vasterman, Peter, Scholten, Otto \& Nel Ruigrok (2008). 'A model for evaluating risk reporting. The case of UMTS and fine particles'. European Journal of Communication, 23 (3): 319-341.

Wien, Charlotte \& Christian Elmelund-Præstekær (2009). 'An anatomy of media hypes developing a model for the dynamics and structure of intense media coverage of single issues'. European Journal of Communication, 24 (2): 183-201. 
Wodak, Ruth (2005). 'Understanding and explaining social change: 'Déjà-vu' experiences'. International Journal of Applied Linguistics, 15 (2): 240-243.

Zinn, Jens (2008). 'A comparison of sociological theorizing on risk and uncertainty'. In: Idem (ed.). Social theories of risk and uncertainty: An introduction. Oxford: Blackwell Publishing.

\section{About the authors}

Andrea Cerase $(\mathrm{PhD})$ is a media and culture sociologist, who has been working over the years on topics such as discrimination, racism and media portrayals of minorities. He has been a Research Fellow at La Sapienza University of Rome and also taught as adjunct lecturer at Florence and Sassari Universities. He also carries on research activities on risk communication, risk issues, journalism and applied social network analysis.

Claudia Santoro. Following her post-graduate degree in communication systems and international relations, Claudia Santoro has been studying the social implications of migrant and minorities (mis)representation within various transnational and national projects, which she designed and managed. Covering communication and research roles, she also works on integration and anti-discrimination with the Italian organization Progetti Sociali, and collaborated with various UK-based NGOs. 